\title{
INVESTIGATING PUBLIC HESITATION IN PAYING TAXES
}

\author{
Lenny Krisnawati \\ Undiknas Graduate School \\ d1d2twince@gmail.com

\begin{tabular}{|c|c|c|}
\hline Received: DD/MM/YYYY & Revised: DD/MM/YYYY & Published: DD/MM/YYYY \\
\hline
\end{tabular}

\begin{abstract}
-
Taxes are the biggest contributor to the state budget portion, but unfortunately the level of public awareness in paying taxes is still very low. The purpose of this study is to investigate the causes of public hesitation in reporting the Annual Tax Return (SPT) and making tax payments, especially for non-employee taxpayers at KPP Pratama Denpasar Timur (Denpasar Timur Tax Office). This research uses a qualitative approach method with purposive sampling technique. The location of this research is at Denpasar Timur Tax Office. The reason for choosing this location is because the Denpasar Timur Tax Office is located in the center of Denpasar city which has a large number of taxpayers with various business classifications, and for the tax year 2018 to 2020 there has been a significant decrease in the number of annual tax returns and tax payments from previous years. Data collection was carried out by in-depth interviews and through virtual interviews, observations and document analysis. The interviewees in this study were non-employee individual taxpayers who were registered at KPP Pratama Denpasar Timur with the criteria of obeying the payment and reporting of Annual SPT, often late in making payments and reporting of Annual SPT, and taxpayers with the criteria of never making payments and reporting the Annual SPT. From the research results, data shows that public doubts in paying taxes are influenced by the absence of direct remuneration received by taxpayers, the covid-19 pandemic that paralyzed most of the community's economy, limited knowledge and understanding of taxation and the limited ability of taxpayers to utilize online facilities which has been provided by the Directorate General of Taxes.
\end{abstract}

Keywords: Taxpayer awareness, knowledge in the field of taxation and effectiveness of the taxation system

\section{INTRODUCTION}

In accordance with Article 1 paragraph 1 of Law Number 6 of 1983 concerning General Provisions and Tax Procedures as amended by Law Number 16 of 2009 it is explained that taxes are payments made by private persons or business entities which are compelling to the state based on Law, without receiving direct compensation and used to finance the needs of the country for the welfare of its people. Tax contribution to state revenue is very important. In the 2019 State Budget, tax revenue is

recorded as contributing $80.9 \%$ of total state revenue.

This is not followed by the same level of public awareness in paying taxes. The low level of public awareness in paying taxes causes the level of tax revenue to be a far cry from the target set by the government. So that the amount of revenue from the taxation sector is not able to support the economic activities that have been determined by the government. This reality is indicated by the Indonesian tax ratio index. In 2018, Indonesia's tax ratio reached only $11.5 \%$, this means that the total revenue from the taxation sector that can be collected by the state is only around $11.5 \%$ of Indonesia's total economic activity. The level of compliance with tax payments can be seen from the tax ratio owned by a country (Nurisdiyanto, 2019) 
As a developing country, it is very difficult for Indonesia to raise its people's awareness to make tax payments. The reasons that cause the public to still have hesitancy in paying taxes, or even indifferent about taxes are the low level of public trust in the Directorate General of Taxes, the low level of public trust in tax officers, the low level of public awareness, the lack of public awareness of tax regulations and the lack of socialization in the field of taxation (Afrianto, 2016)

The perception of tax corruption by tax officials is the main problem of why people are reluctant to pay taxes. This is reinforced by research conducted by (Safitri \& Tambun, 2017) which obtained data that tax corruption by tax officials greatly affects taxpayer compliance. Meanwhile (Meidya Rachmania et al., 2016) in their research, it was found that tax corruption by tax officers had no significant effect on taxpayer compliance.

Low public awareness is also a factor in public reluctance in making tax payments. Many people are not aware of the importance of taxes in sustaining the country's economy. To support the wheels of development so as to create equitable welfare, awareness from the public is needed to increase compliance in paying taxes. In line with previous research conducted by (Rama, 2019) and (Dhea Mayang Pangesti, 2019) that the level of awareness of taxpayers greatly affects the willingness to pay taxes. Meanwhile (Safitri \& Tambun, 2017), (Kisniati, 2019) and (Zahra, 2017) state that the level of taxpayer awareness has no effect on the willingness to pay taxes.

To foster willingness in paying taxes, knowledge and understanding of tax regulations is important for taxpayers because the Indonesian government has implemented a tax collection based on self-assessment system. Based on this system, the public is given the confidence and freedom to make calculations, payments, and self-report their taxes by using a form known as an Annual Tax Return (SPT). In filling out the SPT, it should be done correctly, completely and clearly. If the taxpayer knows clearly the tax regulations, the taxpayer will have the awareness to pay their income tax. This is reinforced by research conducted by (Kisniati, 2019) and (Rama, 2019) that knowledge and understanding of tax regulations greatly affects the willingness to pay taxes.
Meanwhile (Sa'idah et al., 2019) stated that knowledge and understanding of tax regulations had no effect on the willingness to pay taxes.

Public hesitation in paying taxes are also influenced by the perceived difficulty of the tax reporting system or the perception of the effectiveness of the tax system. For this reason, the DGT has made innovations to make the payment system easier, namely by using ebilling, and the tax reporting system using efilling and e-form which can make it easier for taxpayers to carry out their obligations. Taxpayers are no longer need to come to the bank or registered post office to make payments, by using the internet banking application, all services that were previously only accessible by banks or tax offices can now be done at home. Likewise, to report tax obligations, taxpayers are no longer need to come to the tax office to report SPT. Taxpayers can do this by using their smartphone to report their SPT. Taxpayers can take advantage of the facilities provided by the Directorate General of Taxes in making tax reporting. This statement is supported by research conducted by (Dhea Mayang Pangesti, 2019) and (Kisniati, 2019) which states that the willingness to pay taxes will be greatly influenced by a good perception of the effectiveness of the tax system. Meanwhile, according to (Zahra, 2017) and (Sa'idah et al., 2019), taxpayer compliance is not influenced by perceptions of the effectiveness of the tax system.

Related to the existence of various factors that cause public reluctance in paying taxes, the authors are interested in "Investigating Public Hesitation in Paying Taxes", especially individual non-employee taxpayers who are registered at the Denpasar Timur Tax Office. Based on the description in the background, the formulation of the problem is to what extent the public hesitation in paying taxes, especially for individual non-employee taxpayers who are registered at Denpasar Timur Tax Office?

Overall, this study aims to determine the extent of public hesitation in paying taxes, especially individual non-employee taxpayers who are registered at Denpasar Timur Tax Office. This research is expected to provide input and reference to the development of science and technology related to the same discussion as this research and can be taken into consideration in the preparation of further research. Besides, this 
research can provide more and broader knowledge about the factors that affect public hesitation in paying taxes and as an evaluation material and input for tax officers which can be used as a benchmark in providing services to taxpayers.

\section{CONCEPT AND HYPOTHESIS \\ Public hesitation in paying taxes}

There are several factors that can hinder public awareness in paying taxes, namely the lack of knowledge of taxation owned by business actors, lack of socialization in the field of taxation, and the low level of public trust in tax officials (Anugrah Noor R, 2017).

According to research conducted by (Putra Yasa et al., 2019) there are two reasons that cause public hesitation in paying taxes, the first is the people's fear when participating in the tax amnesty program that the money they paid has been corrupted by tax officials and secondly because the tax amnesty program was not participated by all taxpayers.

Until now, public awareness in paying taxes has not reached the expected level. In general, people are still cynical and do not trust in the tax system because they still consider it as tribute to the government, are burdensome, the payments are often troubling, public lack of understanding of what and how taxes are and the difficulties in calculating and reporting them. However, there are still efforts that can be done so that people are fully aware of paying taxes and this is not something that is impossible. When the public has awareness, paying taxes will be done voluntarily, without compulsion.

\section{Perceptions of Tax Corruption}

According to Law No. 31 of 1999 as amended by Law No. 21 of 2001 concerning the $\mathrm{KPK}$, corruption is an act with the aim of enriching oneself, harming other parties, both individuals and corporations. Meanwhile, according to Lopa, quoted by Safroni (2012: 102) in (Meidya Rachmania et al., 2016) corruption means bribery or manipulation related to actions that harm state finances.

(Rika Kartika, Ulfi Jefri, 2020) stated that the perception of tax corruption is the perception of taxpayers in the form of bribery or manipulation to enrich themselves so that they are detrimental to state finances. The perception of tax corruption is the direct submission of the misuse of wealth obtained from paying taxes that should be received by the state for personal gain (Indrawati, 2019)

From these definitions, it can be concluded that corruption is an act that is against the law, by enriching oneself and harming other parties, and causing losses to the state treasury.

\section{Knowledge and Understanding of Tax Regulations}

According to (Kisniati, 2019) knowledge is a change in the work of a mindset from not understanding to understanding and eliminating doubts about a problem. Meanwhile, understanding is the ability to get meaning and comprehension from the material being studied. Knowledge and understanding of tax regulations constitutes reasoning and capturing the meaning of tax regulations.

According to (Faizin et al., 2016) in (Priono, 2019) taxpayers will feel they have no obligation to pay taxes if they do not have awareness and knowledge of the provisions of tax laws and regulations. Tax knowledge is all information that is understood and possessed by taxpayers regarding taxation laws and regulations regarding the tariff rates that have been determined based on law to be obeyed in carrying out their obligations and obtaining their rights as taxpayers for the public interest (Adi Rahman, Siti Paujiah, Anthonius J. Karsudjono, 2020). Understanding is a process carried out by a person to further improve reasoning in order to produce a truth about an issue that is to be known (Sulistyorini, 2019)

It is not easy to determine the tax rate for taxpayers. If a tax is set too high, then the public will be reluctant to pay the tax due. And if it is set too low, the country's development will not run smoothly according to the program planned by the government, because it will hamper all processes caused by a lack of funds.

In order not to cause errors in determining the amount of tax to be imposed on each taxpayer, the tax imposition system must meet the following requirements:

1. The tax imposition system must not be biased. In determining the tax rate, it should be able to create a balance and a sense of fairness for taxpayers and in accordance with the stipulated laws and regulations and 
in its implementation should not create gaps for taxpayers.

2. Tax imposition must be effective and efficient. Taxes should be imposed on the income received by taxpayers after deducting the costs incurred and the tax should only be imposed on end consumers according to the prevailing laws and regulations.

3. The taxation system must be easy to understand. The government should make it easier for taxpayers to calculate the taxes imposed. Simplification of rates and ease of calculating taxes and ease in making tax payments are incentives so that taxpayers can make payments quickly and accurately. On the other hand, if the tax calculation system is difficult to understand, the taxpayer will be lazy to make tax payments.

From the above understanding, it can be concluded that knowledge and understanding of tax regulations is a process by which taxpayers can understand the regulations in the field of taxation and can use their knowledge to make payments and reports in accordance with their obligations.

\section{Tax System Effectiveness}

According to Widayati and Nurlis (2010) in (Sa'idah et al., 2019) effectiveness means a way to find out how many targets have been achieved in terms of quality, quantity and time. The level of effectiveness of the taxation system that can now be felt by taxpayers includes, among others, the existence of a payment system through e-banking which makes it easier for taxpayers to make tax payments, by utilizing ATM, mobile banking and internet banking facilities, taxpayers can make tax payments. without having to queue at the Bank or Post Office.

The perception of the effectiveness of the taxation system is a process carried out by taxpayers in providing responses and assessments in measuring an ongoing tax system. The perception in question is to assess a system whether the system can make it easier for taxpayers or vice versa (Rachmad Putra Ramadhan, Dr. Syaikhul Fallah., SE., M.Si, Mariolin Sanggenafa, SE., M.SA., 2019).

According to (Wulandara \& Adnan, 2019) the effectiveness of the taxation system is an assessment that is given directly by a person of the taxation system being applied, which causes a measurement of how far the target can be achieved with the modern tax system.

According to (Zahra, 2017) the effectiveness of the current tax system can be felt by taxpayers, including:

a. There is an online reporting system using eSPT, e-filling and E-Form. With this online service, taxpayers can report their obligations quickly and easily via their Smartphone

b. Payment via internet banking that can be made with personal cellphone so that it will make it easier for taxpayers without having to queue at the Bank or Post Office.

c. All tax regulations can be accessed online through the website www.pajak.go.id

d. The procedure for registering a Taxpayer Identification Number (NPWP) which can be done by taxpayers themselves online through the site www.eregistration.pajak.go.id without having to come to the nearest Tax Office (KPP) and within 1 x 24 hours the NPWP can already be used by the taxpayers.

From the above understanding, it can be concluded that the effectiveness of the taxation system is a condition that shows the level of success or achievement of a goal as measured by quality, quantity, and time, toward a system in the implementation of tax calculation, payment and reporting according to what was previously planned.

\section{Taxpayer Awareness}

According to (Ferdinawan Ilham Jaya, 2019) consciousness is an element in humans to understand reality and how they act or behave towards reality. Consciousness is a condition in which a person knows or understands, so it can be interpreted that taxation awareness is a condition in which a person knows and understands what their rights are and what their tax obligations are. Taxpayer awareness can be seen from the seriousness and desire of taxpayers in fulfilling their tax obligations (Safitri \& Tambun, 2017).

The form of tax awareness that encourages taxpayers to pay taxes according to (Kisniati, 2019) is:

a. Awareness that taxes are a form of participation in supporting state development. By realizing this, taxpayers 
are willing to pay taxes because they feel they are not going to be disadvantaged by the tax collection that is carried out

b. The awareness that delays in paying taxes and reducing the tax burden are very detrimental to the state. Taxpayers are willing to pay taxes because they understand that delays in paying taxes and reducing tax burdens have an impact on a lack of financial resources that can hamper the country's development

c. Awareness that taxes are established by law and can be enforced. Taxpayers will pay because it is recognized that paying taxes has a strong legal basis and is an absolute obligation of every citizen.

So according to the above understanding it can be concluded that the awareness of taxpayers in paying taxes on time will affect the level of taxpayer compliance. The problem that often occurs related to this tax collection is that there are still many people who do not want to fulfill their tax obligations, or in other words, there are still many unrealized taxes.

\section{Research Framework}

Picture 1.1

conceptual framework

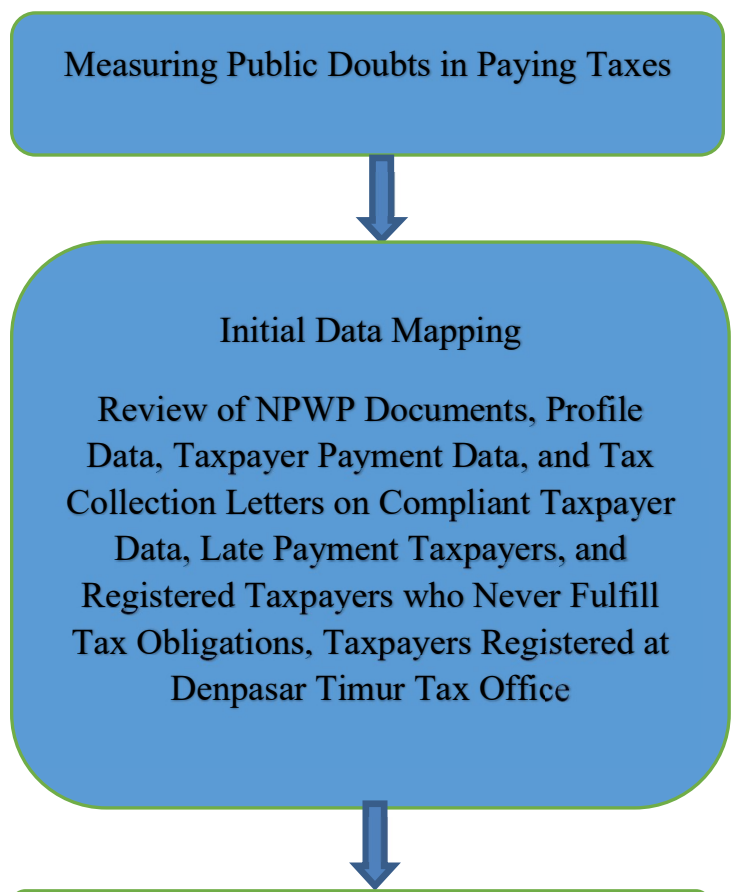

Finding obstacles in paying taxes

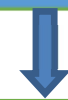

1. Conducting In-Depth Interviews with Taxpayers

2. Making observations at the research location

3. Perform Data Collection

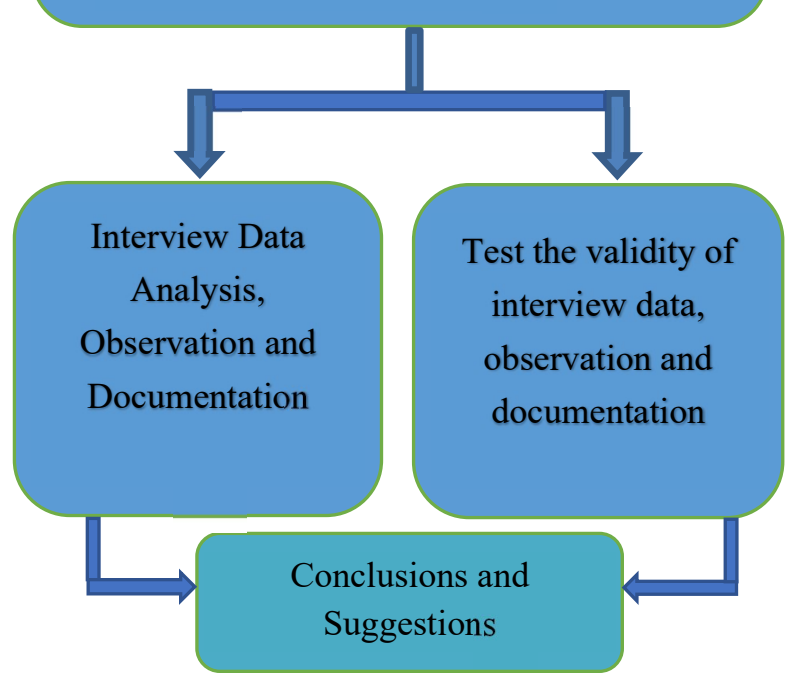




\section{METHOD}

This research is an exploratory study using a qualitative approach with a case study research design. The reason for using qualitative research methods is because researcher want to make observations and get information directly from data sources through direct in-depth interviews with taxpayers and by using virtual interviews, namely through the zoom meeting application, observation and documentation of data that has been collected. The location of this research is at KPP Pratama Denpasar Timur (Denpasar Timur Tax Office). The reason for choosing this location is because the Denpasar Timur Tax Office is located in the center of Denpasar city which has a large number of taxpayers with various business classifications and for the tax year 2018 to 2020 there has been a significant decrease in the number of annual SPT reporting compliance and the number of tax payments from previous years. Additionally, the characteristics of taxpayers also vary, starting from small, medium and large businesses.

In this study, data collection was carried out by means of interviews and collecting documents obtained at the research location. To determine the interviewees in this study, it was carried out with certain considerations or known as purposive sampling technique. The purposive sampling technique of selecting samples according to (Creswell.J.W, 2015) is a sampling technique to obtain data sources by selecting individuals and places to study because they can specifically provide an understanding of research problems and phenomena in this study.

Based on the purposive sampling technique, 6 (six) taxpayers were selected according to predetermined criteria, which were divided into 2 (two) taxpayers with the criteria of obeying the reporting and payment of taxes, 2 (two) taxpayers with the criteria of often being late in doing reporting and paying taxes and 2 (two) taxpayers with the criteria of never reporting and paying taxes. After obtaining data from interviews and existing documents, the data was immediately studied, summarized and analyzed throughout the research.

This study uses data analysis techniques following the Mile and Huberman model (Lune, H., \& Berg, 2017), where data analysis is carried out in 4 stages, namely:
1. Data Collection

The first step in analyzing the data is that the data that has been collected in the field are recorded and examined in detail

2. Data Reduction

The second step is to summarize the results of the interview, choose the main thing, focus on the important things, look for patterns and themes.

3. Data Display (Presentation of Data) The third step is to present the data in the form of a brief description, the relationship between categories to make it easier to draw conclusions from the research that has been done

4. Conclusion Drawing / Verification

The final step is drawing conclusions and verification of data collection obtained during the study. The data obtained during the field research that has been separated are then compiled to find relevance to the point of drawing conclusions.

To strengthen the conclusions of this study, of course, re-verification is needed. In this study, data triangulation techniques were used to draw valid conclusions. There are three data triangulation techniques used, namely source triangulation which is the process of verifying data using various sources, triangulation of data collection techniques is a process of rechecking in various ways, and time triangulation is used to validate data at various times (Lune, H., \& Berg, 2017)

\section{RESULT AND DISCUSSION}

The results of research in the field provide data from two sources, namely primary data obtained from in-depth interviews with interviewees conducted by direct interviews and through zoom meetings in accordance with the interview guidelines that have been prepared. Interviews were conducted with 6 (six) selected interviewees who are nonemployee individual taxpayers registered at KPP Pratama Denpasar Timur with predetermined criteria. While secondary data is obtained from taxpayer data contained in the taxpayer master file obtained from documentation studies in the form of taxpayer identification numbers (NPWP), taxpayer profiles, proof of tax payments, tax bills and compliance data for Annual SPT reporting for the tax years of 2018 and 2019 and the payment 
of individual non-employee taxpayers for the tax years of 2019 and 2020.

Judging from the data on taxpayer compliance in submitting annual tax returns and tax payment of non-employee individual taxpayers from 2018 to 2020 , the percentage of taxpayer compliance has decreased significantly. For the reporting of Annual Tax Return of non-employee individual taxpayers for the 2018 tax year, the number of taxpayers who report Annual SPT is 7,699 of the total registered taxpayers of 11,638 or with a compliance rate of submitting Annual SPT of $70 \%$. However, the Annual SPT of nonemployee individual taxpayers for 2019 has decreased, where the number of taxpayers who filed Annual SPT is only 6,753 from 11,638 registered taxpayers or with a compliance rate of $59 \%$. In the last two years, the taxpayer compliance rate has decreased by $11 \%$.

Not only has the level of compliance of Annual SPT reporting decreased, the level of tax revenue has also decreased in the last 2 (two) years. In 2019, the total payment of nonemployee individual taxpayers registered at Denpasar Timur Tax Office was IDR $120,625,399,413$, but in 2020 the amount of revenue only reached IDR $75,107,295,230$, or decreased by $38 \%$ or IDR $45,518,104,183$, from the previous year. The graphic depiction of the decrease in the level of compliance in reporting the Annual SPT and the payment of individual non-employee taxpayers at Denpasar Timur Tax Office is shown explicitly in diagrams 1 and 2 on the right.

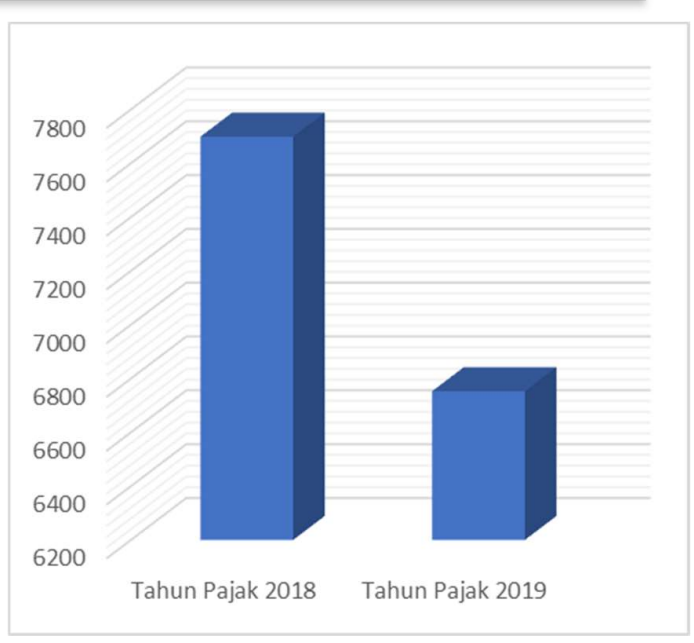

Diagram 1

Compliance Level for Submitting Annual Tax Return of Non-Employee Individual Taxpayers at KPP Pratama Denpasar Timur

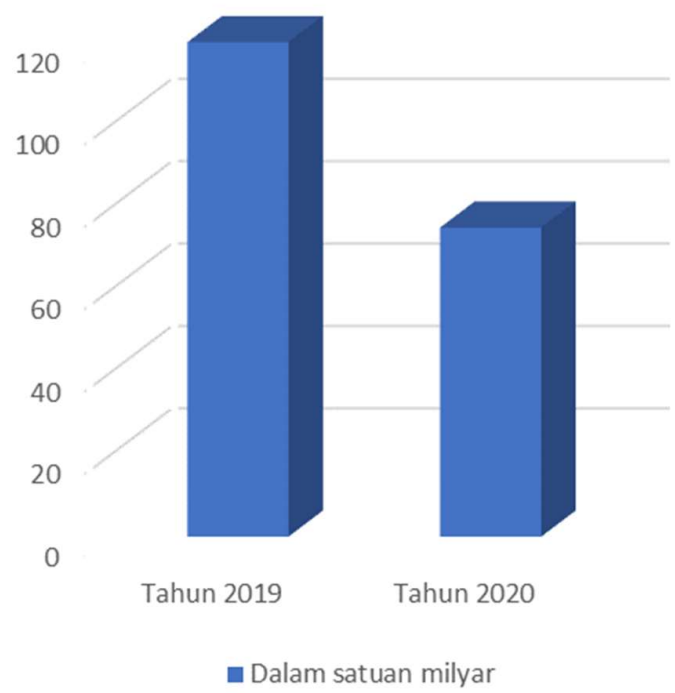

Diagram 2.

Personal non-employee taxpayer payment data at KPP Pratama Denpasar Timur 
In interviews conducted with interviewees who are non-employee individual taxpayers who are registered at Denpasar Timur Tax Office, everyone is agree that taxes are the largest contributor to the state budget besides revenues from exports of goods and oil and gas, and debt.

Based on statistical data, state revenue comes from tax revenue, non-tax revenue and grants, according to diagram 3:

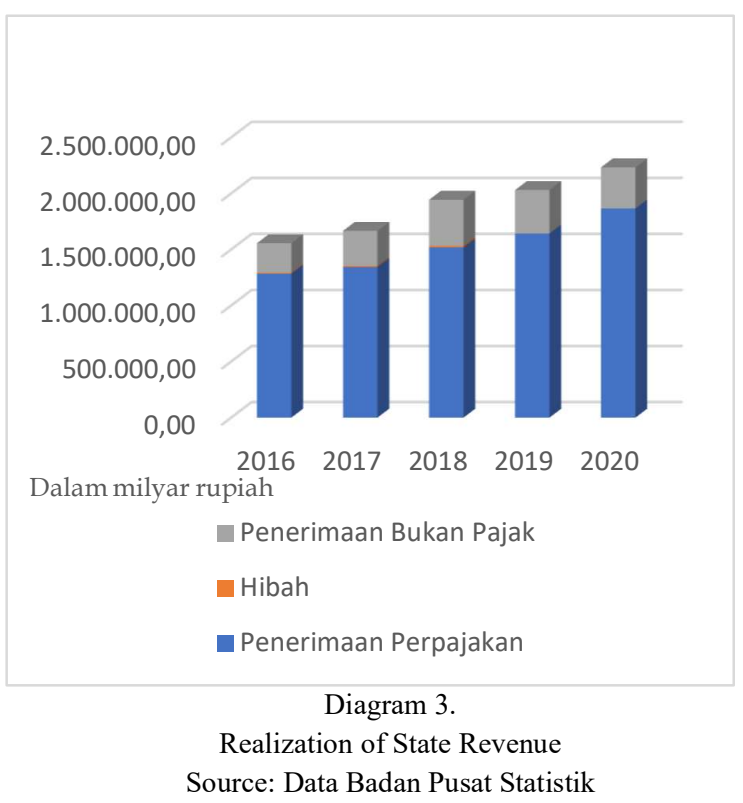

Taxes are the largest source of revenue expected by the state to support the wheels of the country's economy. However, the level of public awareness in paying taxes is still a far cry. The low level of compliance with the submission of annual tax returns and tax payments is due to the low level of public awareness in reporting and payments. The low level of public awareness in making tax payments is due to the fact that people do not feel the direct benefits of paying taxes.

In accordance with Article 1 paragraph 1 of Law Number 6 of 1983 concerning General Provisions and Tax Procedures as amended by Law Number 16 of 2009, taxes are mandatory contributions to the state that are owed by private persons or entities that are compelling under the law, without receiving direct compensation and used for the state's needs for the greatest prosperity of the people.

In an interview with an interviewee who is an MSME actor in the Sumerta Klod subdistrict, he stated that public awareness in paying taxes is still low because according to him: "I do not feel the direct benefit of paying taxes, I feel afraid and have difficulty dealing with taxes."

Another interviewee also argued that public awareness in paying taxes still very low because when they hear about taxes, they usually become defensive, shut themselves off, this is a fact that happens in the field. In fact, if we have earned any income, we will be able to help or build the country, we should be aware of taxes, who else will help the state, because taxes are the source of income for the state. " "In order to increase the public awareness in paying taxes, we should start from the Pakraman village, for example now the property tax (PBB) notification letter have been handed over to the Community's Head, Head of Service, it is them who play an active role and explain to the people to pay taxes, and the village officials also should start explaining what are the benefits of taxes for the state development, we are able to take advantage of the facilities provided by the state if we have paid taxes, but nowadays many people still shut themselves off on that matter."

The factors that can affect the willingness of taxpayers to pay taxes are the awareness of the taxpayers themselves and the reasons that can encourage taxpayers to make payments of their obligations, which is the taxpayers must understand the benefits of the taxes they paid, and taxpayers must realize that paying taxes is the form of citizen's contribution to their country in order to build the country, and taxpayers have the belief that paying taxes will have an impact on business progress (Dhea Mayang Pangesti, 2019)

In the interviews conducted with 6 (six) interviewees, none of them stated that their reluctance in paying taxes are due to the perception of corruption by the tax officials. One interviewee said that: "If corruption is committed by individuals, corruption is not only done in the taxation sector, there may be in all lines, we don't have to worry that someone is guilty, if someone commited corruption, it is not all tax officials are guilty. But the purpose of tax is to develop, provide the government with state 
revenue, which is then utilized to provide facilities for the public. We don't have to worry about corruption, don't use it as an excuse that the money might be corrupted so that we end up not paying taxes. " Other interviewee also argued that "corruption is a moral problem, nowadays corruption in the Dinas or other agencies happened more often than in the Tax Offices, even many members of the House of Representatives (DPR) are corrupt, they are very detrimental to the public and should be given severe punishment because the sentences received so far seem to be less severe, may be death penalty or wealth impoverishing should be given to the perpetrator as conducted in other countries. Other interviewee argue that today's tax officers are more modern and more friendly to the taxpayers. "It is different from the situation in the past when during the New Order era people were looked for in their houses, before they were being chased by tricks and so on, actually it was upsetting. But now this has changed. Taxpayers who come to the Tax Office are given an understanding and so on, their energy is different now, the way they provide an understanding is not as scary as before. Human Resources in taxation are now more cooperative, and in providing services are very polite and there is no element of coercion to give rewards for services that have been provided and all services in the field of taxation are free of charge."

Public trust in tax officers is needed and to create a trusting attitude from the public, it should be seen from how tax officers behave and act when carrying out their duties (Suciaty, 2013) in (Meidya Rachmania et al., 2016). If the tax officer commits the act of embezzling money, it will make the Indonesian people have a negative perception of tax agencies and tax officials, and this will encourage taxpayers to tend to be disobedient (Susanto, 2013) in (Meidya Rachmania et al., 2016) ). On the other hand, if the tax officer does things in accordance with the applicable regulations, it will be easier to urge taxpayers to comply with their obligations.

Lack of understanding and knowledge of tax regulations seems to be greatly influencing public hesitation in paying taxes. This is confirmed by the 6 (six) interviewees who were interviewed, there were 5 (five) people who stated that they did not know about existing tax regulations, they only heard a glimpse of a television broadcast or website that they happened to see. They just follow the rules that were given by the tax officials. However, regulations in the field of taxation change very quickly, the development of regulations in the field of taxation is very dynamic and if taxpayers are not actively seeking information from tax officials, they may make mistakes in reporting and paying taxes. This was said by an interviewee who owns a building materials shop business, "Honestly, I don't get the details, that the rules are developing very quickly, I can honestly say I didn't listen and didn't read the updated or the latest rules. The Account Representative has never contacted me. But usually, I get the information from broadcast television, YouTube, and Google, sometimes it is distributed there. So, I was actively looking for information myself. Maybe it's the government's hope that the taxpayers should play an active role, so don't blame me if I never report and pay taxes according to the income I get. "

The lack of understanding and knowledge of taxpayers on the provisions of the Taxation Laws can cause taxpayers to feel they have no obligation to pay taxes, so that the level of compliance in Annual SPT reporting and the level of tax revenue will be decreasing (Faizin et al, 2016) in (Priono, 2019).

Taxpayers should be given a better understanding of tax because with qualified knowledge in the field of taxation they will feel more responsible with their tax obligations. Taxpayers who already have an understanding knowledge in the field of taxation will be aware of the rights they have as taxpayers and the obligations that they have to fulfilled, they also know about the tax tariff that have to be applied according to their income, how to make tax payments, how to submit tax reports in accordance with applicable laws and regulations and know what penalties will be imposed in the event of a violation of tax regulations (Ilhamsyah, R., Endang, MG, \& Dewantara, 2016).

Besides that, the current low level of taxpayer compliance is due to the current global economic impact. The existence of the Covid19 virus has completely paralyzed our nation's economy. One interviewee argued that "Since the pandemic starting March 2020, my business 
has almost closed so I can barely pay off debt, fortunately the government has provided incentives related to covid for MSME businesses like myself." "So, it's not that I don't want to pay taxes, but because I have no income, that's why I don't pay taxes."

Regarding the covid-19 pandemic, which caused revenue from the tax sector to greatly decline, many trading businesses and the tourism sector had to be closed due to the largescale social restrictions (PSBB) implemented by the government. With the rules that have been given and set by the government, namely by giving and issuing PMK no. 44 / PMK.03 / 2020 and finally by issuing PMK No. $86 /$ PMK.03 / 2020 concerning tax incentives for taxpayers affected by the Corona Virus Disease 2019 pandemic.

The facilities and infrastructure for reporting and payments used in the current taxation system have developed. Taxpayers no longer need to queue at the bank or post office to make payments. Currently, with the sophistication of technology, taxpayers can make tax payments using a smartphone which first creates an ebilling code in the application provided by the Directorate General of Taxes. To make annual SPT reporting is also very easy, taxpayers do not need to come to the Tax Office to report their Annual Tax Returns, but currently, from a smartphone application, they can also report their Annual Tax Returns by accessing the website www.djponline.pajak.go.id. Is effectiveness in the field of taxation able to assist taxpayers in carrying out their tax obligations?

According to the interviewee who is engaged in the UMKM business, "When I need to pay taxes, I can use the current available technology, I can use a cellphone, I can pay directly, no need to queue anymore. Now, just use mobile banking to make transactions. It is very useful for me, first we save time, we no longer go to the tax office, no longer pay at the post office, even we can make payments from home with e-banking, right? Everything can be done online, everyone can help, so the benefits of technology is very good and I have experienced it myself, and maybe other taxpayers who want to utilize it will definitely feel the benefits and this is a tremendous breakthrough by the Taxation Department. "
Another interviewee argued that "This online system is very good, if there are things that are discovered by the taxation department, that there is no increase in taxpayer compliance to pay taxes, maybe they are constrained here. Because with this online presence, those who can feel the benefits are taxpayers who already have internet (wifi) facilities, are technology literate, not all taxpayers are technology literate, therefore, this is an obstacle. Even though with this online system, everything for people who can use this facility feels light and comfortable, for example me, but for those who don't, this is a problem which they are unable to make payments and reporting online. Because people who are engaged in this business are not all equipped with IT knowledge, and this is one of the weaknesses of the current information system / sophistication. When it is used as an online taxation system, so for those who are not equipped with that knowledge, it will create difficulties. " My suggestion may be that there is a need for another system, which can be utilized by those who cannot take advantage of the current online system, where they can still make conventional payments and reports. " "Once again, my suggestion is that the network of this sophisticated IT system needs to be expanded, moreover it must be able to be utilized by those who are still lacking in IT capabilities."

With the online system currently being implemented by the Directorate General of Taxes, of course it will be a dilemma for taxpayers. For taxpayers who understand how to take advantage of technological advances, maybe this online tool will be very helpful and make it easier for taxpayers to carry out their obligations, but if taxpayers do not understand and do not want to study technological progress themselves, this will make it difficult for taxpayers themselves ( Rachmad Putra Ramadhan, Dr. Syaikhul Fallah., SE., M.Si, Mariolin Sanggenafa, SE., M.SA., 2019)

\section{CONCLUSION}

From the results of the research conducted, it is known that public hesitation in reporting and paying taxes are influenced by the indirect benefits that occurred by paying taxes which cannot be felt immediately by taxpayers, there are still many state infrastructures that have not been developed by the government, which 
causes the people to still lack confidence in the importance of taxes in supporting the country's development, so there are still many people who are hesitant to carry out their obligations in the taxation sector

However, public reluctance in paying taxes are not influenced by perceptions of corruption from tax officials. Taxpayers realize that corruption is not only done by tax officials, but corruption is everywhere, depending on the morale of each individual. So, there is no reason for taxpayers not to pay taxes due to corruption committed by tax officials.

Understanding and knowledge in the field of taxation greatly affects public hesitation in paying taxes. Taxpayers should be given an understanding and knowledge in the field of taxation so that they are aware of the rights they have and the obligations they have to fulfill as taxpayers. Taxpayers should be provided with understanding and knowledge about the procedure in calculating the amount of tax rates imposed on the income they receive, how to make tax payments, and how to submit tax reports correctly, so that the level of taxpayer compliance can be increased.

The low level of tax revenue in 2020 was also caused by the Covid-19 pandemic that hit the world and Indonesia in particular, this caused many taxpayer businesses to close down until they were finally unable to pay taxes like the previous years.

The effectiveness of the tax system greatly affects public hesitation in paying taxes. For taxpayers who understand how to use the online facilities provided by the Directorate General of Taxes, taxpayers will be greatly helped by this convenience. Payment and reporting can be made online, saving time and effort. However, there are weaknesses that occur if this facility cannot be used by taxpayers who have limited capabilities in utilizing highly developed technologies, where they are lazy to learn the new technologies so they do not carry out the obligations they should have done.

Regarding the existing limitations, it is hoped that further research can further explore the steps that can be taken to overcome the limitations of the technological capabilities of taxpayers in using online facilities that have been implemented by the Directorate General of Taxes, so that the results can further increase state revenue from the MSME sector.
Reference

Adi Rahman, Siti Paujiah, Anthonius J. Karsudjono, L. N. (2020). Pengaruh Sistem Perpajakan, Pelayanan Perpajakan, Sanksi Pajak dan Kesadaran Wajib Pajak terhadap Kepatuhan dan Keputusan Membayar Pajak Kendaraan Bermotor pada Samsat Banjarmasin I. Jurnal Mitra Manajemen (JMM Online), 4, 377-391.

Afrianto, D. (2016, September 21). Alasan Rendahnya Kesadaran-Masyarakat Bayar Pajak. Oke Finance. https://economy.okezone.com/read/2016/ 09/21/20/1495183/7

Anugrah Noor R. (2017). Keengganan Wajib Pajak UMKM untuk Mengikti Tax Amnesty. Journal of Chemical Information and Modeling, 53(9), 1689-1699. https://doi.org/10.1017/CBO9781107415 324.004

Creswell.J.W. (2015). Penelitian Kualitatif \& Desain Riset. Pustaka Pelajar.

Dhea Mayang Pangesti, A. N. Y. (2019). Pengaruh Kesadaran Membayar Pajak, Persepsi Atas Efektivitas Sistem Perpajakan, Dan Pemahaman Peraturan Pemerintah Nomor 23 Tahun 2018 Terhadap Kemauan Membayar Pajak (Pada Umkm Sektor Perdagangan Di Kabupaten Klaten). Nominal: Barometer Riset Akuntansi Dan Manajemen, 8(2), 166-178. https://doi.org/10.21831/nominal.v8i2.264 61

Ferdinawan Ilham Jaya. (2019). Pengaruh Kesadaran Membayar Pajak dan Kemudahan Penggunaan E-Filling terhadap Kepatuhan Wajib Pajak Orang Pribadi serta Implikasinya terhadap Kemauan Membayar Pajak (Studi pada Wajib Pajak Orang Pribadi di Kabupaten Yogyakarta). Universitas Islam Indonesia. http://hdl.handle.net/123456789/17994

Ilhamsyah, R., Endang, M.G.,\&Dewantara, R. . (2016). Pengaruh Pemahaman dan Pengetahuan Wajib Pajak tentang Peraturan Perpajakan, Kesadaran Wajib Pajak, Kualitas Pelayanan, dan Sanksi Perpajakan terhadap Kepatuhan Wajib Pajak Kendaraan Bermotor (Studi Samsat Kota Malang). Jurnal Perpajakan (JEJAK), 8.

Indrawati, V. (2019). Pengaruh Persepsi Korupsi, Kualitas Pelayanan, Sanksi Perpajakan, dan Sistem Administrasi Perpajakan Modern terhadap Kepatuhan Wajib Pajak dengan Tingkat Pendidikan 
sebaga Variabel Kontrol.

Kisniati. (2019). Faktor-Faktor Yang Mempengaruhi Kemauan Membayar Pajak Pada Wajib Pajak Orang Pribadi Yang Melakukan Pekerjaan Bebas Di Kpp Pratama Denpasar Timur. Jurnal Sains, Akuntansi Dan Manajemen, 1(1), 254300. https://doi.org/10.1234/jasm.v1i1.29

Lune, H., \& Berg, B. . (2017). Qualitative Research Methods for the Social Sciences (Pearson).

Meidya Rachmania, F., Siti Astuti, E., \& Nayati Utami, H. (2016). Pengaruh Persepsi Korupsi Pajak dan Kualitas Pelayanan Fiskus Terhadap Kepatuhan Wajib Pajak (Studi pada Wajib Pajak Orang Pribadi yang Terdaftar di KPP Pratama Batu). Jurnal Perpajakan (JEJAK), 10(1), 1-8.

Nurisdiyanto, W. E. (2019). Betapa Krusialnya Pajak dalam Portal Kehidupan Berbangsa dan Bernegara. Www.Pajak.Go.Id. https://www.pajak.go.id/id/artikel/betapakrusialnya-pajak-dalam-portal-kehidupanberbangsa-dan-bernegara

Priono, H. (2019). Penerapan Selft Assessment System terhadap Kecenderungan Penghindaran Pajak Penghasilan pada Industri Kecil di Wedoro Sidoarjo. Journal of Chemical Information and Modeling, 53(9), 1689-1699. https://doi.org/10.1017/CBO9781107415 324.004

Putra Yasa, I. N., Sujana, E., \& Andriawan, I. G. D. (2019). Persepsi Wajib Pajak Atas Program Tax Amnesty Dalam Perspektif Budaya Meboya. Jurnal IImiah Akuntansi, 4(1), 66-87. https://doi.org/10.23887/jia.v4i1.16653

Rachmad Putra Ramadhan, Dr. Syaikhul Fallah., SE., M.Si, Mariolin Sanggenafa, SE., M.SA., A. (2019). Pengaruh Pemahaman Peraturan Pajak, Pelayanan Fiskus, Persepsi Efektivitas Perpajakan terhadap Kemauan Membayar Pajak (Studi Empiris pada Kantor Pelayanan Pajak Pratama Jayapura). Jurnal Akuntansi \& Keuangan Daerah, 14(1), 36-53.

Rama, M. (2019). Faktor-Faktor yang Mempengaruhi Kepatuhan Wajib Pajak Usaha Mikro Kecil dan Menengah (UMKM) dalam Membayar Pajak sesuai PP No.23 Tahun 2018 pada UMKM Kabupaten Indragiri Hilir (Inhil). Journal of Chemical Information and Modeling, 53(9), 1689-1699. https://doi.org/10.1017/CBO9781107415 324.004
Rika Kartika, Ulfi Jefri, dan F. S. (2020). Pengaruh Persepsi Korupsi dan Kualitas Pelayanan Fiskus terhadap Kepatuhan Wajib Pajak Orang Pribadi di Kantor Pelayanan Pajak Pratama Cilegon. 4(1), 126-134.

Sa'idah, N., Sari, R. N., \& Ratnawati, V. (2019). Faktor-Faktor Yang Mempengaruhi Kemauan Membayar Pajak (Studi Empiris Wajib Pajak Orang Pribadi Non Karyawan). Jurnal Akuntansi, 7(2), 172184.

Safitri, D., \& Tambun, S. (2017). Pengaruh Kesadaran Wajib Pajak Dan Persepsi Korupsi Pajak Terhadap Kepatuhan Wajib Pajak Dengan Kepercayaan Masyarakat Sebagai Variabel Moderating. Media Akuntansi Perpajakan, 2(2), 23-33. http://journal.uta45jakarta.ac.id/index.php /MAP/article/view/1094

Sulistyorini, D. (2019). Pengaruh Kesadaran Wajib Pajak, Pemahaman Wajib Pajak dan Kualitas Pelayanan Pajak Terhadap Kepatuhan Wajib Pajak (Study Empiris di KPP Pratama Cikarang Selatan). Accounthink: Journal of Accounting and Finance, $\quad 4(2)$, 732-745. https://doi.org/10.35706/acc.v4i2.2202

Wulandara, I. K., \& Adnan. (2019). Pengaruh Modernisasi Sistem Administrasi Perpajakan Dan Efektivitas Sistem Perpajakan Terhadap Kepatuhan Wajib Pajak (Studi Pada Wajib Pajak Orang Pribadi Yang Terdaftar Dikantor Pelayanan Pajak Pratama Banda Aceh). 4(1), 1-12.

Zahra, I. N. (2017). Pengaruh Persepsi atas Efektifitas Sistem Perpajakan dan Pengetahuan Pajak terhadap Kepatuhan Wajib Pajak dengan Kesadaran Membayar Pajak sebagai Variabel Intervening (Studi pada WPOP yang Terdaftar di KPP Pratama Surakarta). 12(1), 145. 